\title{
MAPIRANJE PODRUČJA ISTRAŽIVANJA KREATIVNOSTI I DIZAJNA POSLA: KRONOLOŠKA ANALIZA CITATA I ZAJEDNIČKIH CITATA
}

\section{MAPPING THE FIELD OF RESEARCH ON CREATIVITY AND JOB DESIGN: CHRONOLOGICAL ANALYSIS OF QUOTATIONS AND COMMON QUOTATIONS}

SAŽETAK: Kreativnost je prepoznata kao jedna od važnih preduvjeta za dugoročnu fleksibilnost i opstanak organizacija. S druge strane, dizajn posla jedan je od preduvjeta za kreativno ponašanje, zbog čega je neizostavan u proučavanju tog konstrukta. Cilj ovoga rada je istražiti kronološki razvoj područja kreativnosti i njegove povezanosti s dizajnom posla pomoću bibliometrijskih metoda - analize citata i zajedničkih citata. Iz početnog uzorka od 3241 rada, provedena je analiza kroz tri različita vremenska razdoblja. Za svako vremensko razdoblje istaknuti su i objašnjeni klasteri literature koji odražavaju strukturu i razvoj područja kroz vrijeme. U raspravi su, nakon zaključka, predložene smjernice za buduća istraživanja.

Ključne riječi: kreativnost, dizajn posla, inovativnost, bibliometrijska analiza, analiza zajedničkih citata.

ABSTRACT: Creativity has been recognized as an important precondition for longterm organizational flexibility and survival. Job design, as one of the determinants of creative behavior is indispensable in studying that construct. Therefore, the goal of this paper is to provide a chronological review of development and structure of the creativity literature by using bibliometric methods of citation and co-citation analysis. The analysis has been carried out from the initial sample of 3241 papers through three different time periods. Clusters which reflect the structure and development of the field over time have been highlighted and explained for each time period. Finally, after conclusion, directions for future research have been suggested in the discussion section.

Key words: creativity, job design, innovation, bibliometric analysis, co-citation analysis.

Matija Marić, mag. oec., Asistent, Ekonomski fakultet Sveučilišta u Zagrebu, Trg J. F. Kennedyja 6, 10000

Zagreb, Hrvatska, e-mail: mmaric@efzg.hr 


\section{UVOD}

Smatra se da je kreativnost jedan od ključnih čimbenika koji utječu na stvaranje konkurentske prednosti organizacija (Oldham i Cummings, 1996.). Upravo iz tog razloga ovaj konstrukt proučava se već nekoliko desetljeća u okviru različitih područja i na različitim organizacijskim razinama. Zanimanje za kreativnost započela je u psihologiji, no tek tijekom 1970.-ih godina počinje se proučavati ekstenzivnije u literaturi iz područja ekonomije odnosno menadžmenta. Neizostavna varijabla pri promatranju kreativnosti je dizajn posla. Brojne teorije i kasnija empirijska istraživanja prepoznala su ga kao značajan čimbenik utjecaja na individualnu kreativnost (Amabile, 1983.; Ohly i Fritz, 2010.). Dizajn posla opisuje kako su radna mjesta, zadaci i uloge strukturirani te koji je njihov učinak na individualne, grupne i organizacijske ishode (Grant, 2007.; Grant i Parker, 2009.). Važnost dizajna posla najbolje se može ilustrirati činjenicom da u prosjeku objašnjava $43 \%$ varijance kod 19 različitih oblika stavova i ponašanja zaposlenika (Humphrey i sur., 2007.). Naravno, to se odnosi i na njegov utjecaj na kreativno ponašanje.

Iako već postoje pregledi literature koji povezuju područja dizajna posla i kreativnosti, dosada nije stavljen naglasak na pregled trenutka i razdoblja povezivanja literature iz ova dva područja. Od pojave konstrukta kreativnosti s vremenom je nastalo nekoliko različitih pristupa, a pojavili su se i mnogi slični konstrukti poput primjerice, originalnosti (Barron, 1955.) ili inovativnosti (Siegel i Kaemmerer, 1978.). Jedan od rezultata toga su često nejasne granice između kreativnosti i inovativnosti (Anderson i sur., 2014.). Također, značajan problem u istraživanju kreativnosti je i nedostatak višerazinskih empirijskih istraživanja usprkos nekoliko teorija koje preporučuju takav pristup i nastoje objasniti potencijalne interakcije između različitih razina (Anderson i sur., 2014.). To je posebno iznenađujuće uzevši u obzir da dizajn posla kao važan čimbenik kreativnog ponašanja pojedinca pripada različitoj razini promatranja u odnosu na ishode posla, stavove i ponašanja kod pojedinaca.

Kako bi pokušali riješiti ove probleme u literaturi o kreativnosti, potrebno je pronaći odgovore na dva pitanja. Prvo, kako se područje razvijalo kroz vrijeme? Zatim, kakva je bila struktura područja i koje su teme bile značajne u određenom vremenskom razdoblju? Odgovori na ova pitanja mogu objasniti kako je uopće došlo do problema te identificirati potencijalna rješenja. Iako postoji nekoliko meta-analiza i pregleda literature na temu kreativnosti, bibliometrijska analiza nudi niz prednosti pomoću kojih je moguće doći do novih spoznaja vezano za određeno područje istraživanja. Pomoću bibliometrijske analize moguće je provesti tzv. mapiranje područja, s ciljem identificiranja razlika i povezanosti različitih disciplina i područja (Zupic i Čater, 2015.). Na taj način provodi se objektivna analiza izabranog područja s kvantitativne perspektive (Castillo-Vergara i sur., 2018.). Koliko je autorima poznato, ne postoji rad koji pomoću ove metodologije analizira područja kreativnosti i dizajna posla. Williams i sur. (2016.) su mapirali područje kreativnosti u posljednjih 25 godina, dok su se Castillo-Vergara i sur. (2018.) usredotočili samo na bibliometrijsku analizu područja kreativnosti u poslovnoj ekonomici.

Glavni cilj ovoga rada je pružiti pregled intelektualnog razvoja i strukture područja kreativnosti te njezine povezanosti s dizajnom posla. Isto tako, važno je odrediti trenutak povezivanja područja istraživanja dizajna posla i područja istraživanja kreativnosti. Pri tome će se koristiti prikladne bibliometrijske metode - analizu citata i zajedničkih citata. Analiza zajedničkih citata omogućuje pregled stanja i strukture te faza razvoja pojedinog područja u određenom vremenskom razdoblju (Nerur i sur., 2008.; Vogel i Güttel, 2013.). 


\section{TEORIJSKA POLAZIŠTA O KREATIVNOSTI}

Kreativnost se u organizacijama najčešce promatrala na razini pojedinca. Definira se kao proces koji dovodi do stvaranja novog i korisnog proizvoda, usluge, ideje ili procedure (Woodman i sur., 1993.). Smatra se da dovodi do niza korisnih ishoda za organizacije ako dođe to implementacije tih proizvoda, usluga, ideja ili procedura (Oldham i Cummings, 1996.). Razvidno je da se kreativnost poima uglavnom na razini pojedinca, a povezuje se s pozitivnim ishodima na razini pojedinca, grupe i organizacije. Upravo iz tog razloga važan napredak u području kreativnosti predstavljalo bi istraživanje mehanizama koji povezuju i objašnjavaju utjecaj kreativnosti na različitim razinama te varijable koje su prethodnici kreativnosti na različitim organizacijskim razinama.

Postoji razvijeno teorijsko uporište za višerazinska istraživanja u području kreativnosti. Amabile (1983.) je u svojim radu istaknula potrebu za odmakom od tradicionalnog pristupa koji se temeljio samo na proučavanju osobnosti izrazito kreativnih pojedinaca. Već u tom naglasku na utjecaj okoline posla nazire se višedimenzionalan pogled. Interakcijski pristup prema kojem kreativnost ovisi o kompleksnoj interakciji pojedinaca, grupa i organizacijskih karakteristika te konteksta, predstavlja glavno uporište za višerazinski pogled na kreativnost, ali i inovativnost.

Međutim, za daljnja istraživanja važno je razjasniti primarni problem definicije konstrukta kreativnosti i slične ili povezane inovativnosti odnosno inovativnog ponašanja zaposlenika. Inovativno ponašanje zaposlenika najčešće se definira kao proaktivan proces pojedinca koji obuhvaća nekoliko faza od generiranja ideje do njezine implementacije (Hammond i sur., 2011.). Općenito, inovativnost u organizacijama se proučava na nekoliko razina, a inovativno ponašanje zaposlenika jedan je od ishoda pojedinaca na poslu. Rothaermel i Hess (2007.) ukazuje na činjenicu da se čimbenici utjecaja na inovativnost organizacije nalaze na različitim razinama: mrežnoj, organizacijskoj i individualnoj. Zanemarivanje različitih razina istraživanja upravo je jedan od glavnih razloga za neusklađenost definicija različitih konstrukata.

Mumford i Gustafson (1988.) ukazuju na neusklađenost pojma kreativnosti u literaturi, ali i na druge potencijalne razloge za takvu situaciju. Kako objašnjava, moguće je da postoje različiti oblici kreativnosti, ovisno o okolini i stupnja noviteta ideje (npr. inkrementalna i radikalna promjena). Drazin i sur. (1999.) također ističu da je problem uobičajenog shvaćanja kreativnosti u tome što ono zapravo implicira mjerenje kreativnih outputa, umjesto razine kreativnog ponašanja. Isto tako, potrebno je jasno odrediti razliku između inovativnosti i kreativnosti. Upravo, pregled vremenskog razvoja literature može ponuditi širu sliku o izvorima pojedinih definicija konstrukata i razlika među njima.

Dizajn posla prepoznat je kao jedna od aktivnosti upravljanja ljudskim potencijalima koja može doprinijeti kreativnom i inovativnom ponašanju zaposlenika (Anderson i sur., 2014.; Bos-Nehles i Janssen, 2015., Grant i Parker, 2009.). Isto tako, važno je naglasiti kako neodgovarajući dizajn posla može onemogućiti ili destimulirati kreativno i inovativno ponašanje (Unsworth i Parker, 2003.). Dizajn posla opisuje podjelu, strukturiranje i izmjene zadataka, uloga i posla te učinak ovih aktivnosti na individualnoj, grupnoj i organizacijskoj razini (Grant, 2007.; Grant i Parker, 2009.). Važan je za uspješnost organizacija, ali i za dobrobit njihovih zaposlenika. Brojne koristi mogu proizlaziti iz dobrog dizajna posla: veći stupanj zadovoljstva poslom i predanosti organizaciji (Humphrey, Nahrgang i Morge- 
son 2007.), veći stupanj inovativnosti (Hammond, Neff, Farr, Schwall i Zhao, 2011.), veći financijski prinos (Xanthopoulou, Bakker, Demerouti i Schaufeli, 2009.), veći stupanj organizacijskog građanskog ponašanja (Mayfield, 2013.), veći stupanj inicijative i učenja na poslu (Sonnentag, 2003.) itd. Za današnji pogled na dizajn posla znakovito je naglašavanje njegove socijalne dimenzije, za razliku od dosadašnjeg pogleda usredotočenog uglavnom na skup zadataka te povezivanje dizajna posla s varijablama na različitim organizacijskim razinama (Grant, 2007.; Parker i sur., 2001.).

\section{BIBLIOMETRIJSKA ANALIZA}

\subsection{Podaci i procedura}

Prvi korak u analizi zajedničkih citata je određivanje uzorka odnosno baze dokumenata. Pretraživanje po ključnim riječima provedeno je u Web of Science bazi podataka koristeći sljedeće ključne riječi: „,creativity AND (job design OR work design OR innov* OR "job design” or "work design”)". Cilj ovih ključnih riječi je bio obuhvatiti literaturu o kreativnosti, ali i literaturu o utjecaju dizajnu posla na kreativnost.

Nakon toga, primarna baza radova sužava se prema znanstvenom području i vrsti rada. Izabrana su znanstvena područja menadžmenta i poslovne ekonomije, ekonomike te od radova članci u časopisima, poglavlja u knjigama i radovi objavljeni na konferencijama. To je dovelo do konačne baze od 3241 rada. Ova konačna baza se za potrebe analize filtrirala prema 3 vremenska razdoblja: prvo - do 1999. godine, drugo - od 2000. do 2009. godine i treće - od 2010. do 2019. godine. Navedena razdoblja formirana su na temelju ključnih radova u području istraživanja. Također, s obzirom na narav bibliometrijske analize bila su poželjna približno jednaka vremenska razdoblja odnosno postojala je potreba za određenim brojem radova u svakom razdoblju. U razdoblju do 1999. godine bio je $91 \mathrm{rad}$, u razdoblju od 2000. do 2009. godine bilo je 447 radova, a u razdoblju od 2010. do 2019. godine bilo je 2703 radova.

Radovi svakog razdoblja poredani su prema kriteriju relevantnosti u Web of Science bazi podataka. Takvo rangiranje uzima u obzir u kojoj mjeri se naslov, sažetak i ključne riječi svakog rada poklapaju sa zadanim ključnim riječima u pretraživanju. Zatim su izvezeni podaci o referencama najrelevantnijih 250 radova u svakom razdoblju analize. Dakle, u razdoblju do 1999. godine bio je $91 \mathrm{rad}$, dok je u razdoblju od 2000. do 2009. godine te od 2010. do 2019. izvezeno po 250 radova.

Nakon pripreme konačne baze, korišten je softverski alat VOS Viewer pomoću kojeg je moguće provesti razne oblike mapiranja područja istraživanja, kao i druge analize. Ovaj softver radi na pristupu koji se temelji na udaljenosti objekata analize (npr. autor, časopis, ključna riječ itd.). Udaljenost dva objekta ovisi o njihovoj povezanosti (van Eck i Waltman, 2014.). Dakle, što je veća udaljenost između dvije točke na prikazu, to je manja povezanost između ta dva objekta. Vrijedi i obratno, što je veća udaljenost između dvije točke na prikazu, to je veća povezanost između dva objekta. Metoda za izračun lokacije pojedinih točaka (objekata) koju koristi VOS Viewer je tzv. VOS tehnika, a detaljnije je objašnjena u radu Van Ecka, Waltmana, Dekkera i Van den Berga (2010.). 


\subsection{Rezultati}

Prvo je provedena osnovna analiza citata na konačnoj bazi radova, s ciljem prikaza osnovnih karakteristika područja dizajna posla i kreativnosti. Pomoću VOS Viewera izdvojeni su ključni radovi, ključni autori i ključni časopisi za ovo područje. Kao primarni kriterij značajnosti za sve kategorije (radovi, autori i časopisi) korišten je broj međusobnih citata unutar područja. Ovaj kriterij vrlo je važan kako bi fokus analize bio na odnosu između kreativnosti i dizajna posla. Očekivano je da će se radovi unutar jednog područja međusobno citirati (Zupic i Čater, 2015.).

Glavni radovi u području prikazani su u tablici 1. Najrelevantniji radovi su oni s najvećim brojem međusobnih veza unutar područja. Ako se uzme u obzir i citiranost pojedinog rada, najviše se ističu tri rada. Prvo, rad pod naslovom „Assessing the work environment for creativity" objavljen u Academy of Management Journal, u kojem je razvijen novi mjerni instrument za mjerenje kontekstualnih varijabli koje potiču kreativnost. Drugo, rad naslovljen „Toward a theory of organizational creativity“ objavljen u Academy of Management Review, koji predstavlja početak interakcijskog pristupa kreativnosti. Treće, rad pod naslovom „Determinants of Innovative Behavior: A path model of individual innovation in the workplace“" objavljen također u Academy of Management Journal. U ovom radu definiran je novi konstrukt inovativnog ponašanja na razini zaposlenika i jasno je određena granica između kreativnog i inovativnog ponašanja.

Tablica 1. Citiranost značajnih radova

\begin{tabular}{|l|r|r|c|}
\hline \multicolumn{1}{|c|}{ Naslov rada } & $\begin{array}{c}\text { Godina } \\
\text { objave }\end{array}$ & $\begin{array}{c}\text { Broj } \\
\text { citata }\end{array}$ & $\begin{array}{c}\text { Broj } \\
\text { međusobnih } \\
\text { veza }\end{array}$ \\
\hline Assessing the work environment for creativity & 1996. & 1949 & 120 \\
\hline Toward a theory of organizational creativity & 1993. & 1542 & 106 \\
\hline $\begin{array}{l}\text { Determinants of Innovative Behavior: A path model of } \\
\text { individual innovation in the workplace }\end{array}$ & 1994. & 1667 & 82 \\
\hline $\begin{array}{l}\text { An examination of leadership and employee creativity: } \\
\text { The relevance of traits and relationships }\end{array}$ & 1999. & 607 & 53 \\
\hline $\begin{array}{l}\text { Transformational leadership, conservation, and } \\
\text { creativity: Evidence from Korea }\end{array}$ & 2003. & 557 & 35 \\
\hline $\begin{array}{l}\text { Creative Self-Efficacy: Its potential antecedents and } \\
\text { relationship to creative performance }\end{array}$ & 2002. & 711 & 34 \\
\hline $\begin{array}{l}\text { Motivating creativity in organizations: On doing what } \\
\text { you love and loving what you do }\end{array}$ & 1997. & 592 & 30 \\
\hline $\begin{array}{l}\text { Shopfloor innovation: Facilitating the suggestion and } \\
\text { implementation of ideas }\end{array}$ & 2000. & 414 & 29 \\
\hline $\begin{array}{l}\text { The social side of creativity: A static and dynamic social } \\
\text { network perspective }\end{array}$ & 2003. & 649 & 28 \\
\hline $\begin{array}{l}\text { Matching creativity requirements and the work } \\
\text { environment: Effects on satisfaction and intentions to } \\
\text { leave }\end{array}$ & 2000. & 288 & 28 \\
\hline
\end{tabular}


Najznačajniji autori, prema kriteriju međusobnih citata unutar područja, su Teresa $\mathbf{M}$. Amabile (123 međusobna citata), Steven M. Farmer i Pamela Tierney (svaki po 75 međusobnih citata). Ostali autori značajni u području su Kerrie L. Unsworth, Sandra Ohly, Jing Zhou, Toby D. Wall, Carolyn M. Axtell, Abraham Carmeli i David Holman. Najveći broj objavljenih radova u području imaju Teresa Amabile (7 radova) i Jing Zhou (6 radova). Ako se uzme u obzir citiranost pojedinog autora, najznačajniji su Teresa Amabile (5573 citata), Steven M. Farmer i Pamela Tierney (svaki po 1827 citata) te Jing Zhou (1320 citata). Na temelju analize najznačajnijih radova i autora, vidljiva je međusobna povezanost područja inovativnosti s kreativnosti i dizajnom posla.

Ključni časopisi u kojima su objavljeni radovi iz područja kreativnosti i dizajna posla prikazani su u tablici 2. Daleko najviše radova objavljeno je u Academy of Management Journal-u i Personnel Review-u. Ipak, uzevši u obzir relevantnost unutar područja dizajna posla i kreativnosti, većina najznačajnijih radova objavljena je u sljedećih deset časopisa: Academy of Management Journal, Leadership Quarterly, Journal of Applied Psychology, Journal of Organizational Behavior, Journal of Occupational and Organizational Psychology, Journal of Management, European Journal of Work and Organizational Psychology, Personnel Review, Organization Science i Leadership and Organization Development. Iz provedene analize vidljivo je u kojim časopisima se događala većina istraživanja u području tijekom vremena, a vrlo je vjerojatno da će u istim časopisima biti objavljena ključna nova istraživanja.

Tablica 2. Pregled časopisa u kojima su objavljeni značajni radovi

\begin{tabular}{|l|c|c|c|}
\hline \multicolumn{1}{|c|}{ Časopis } & $\begin{array}{c}\text { Broj objavljenih } \\
\text { radova }\end{array}$ & Broj citata & $\begin{array}{c}\text { Broj međusobnih } \\
\text { veza }\end{array}$ \\
\hline Academy of Management Journal & 18 & 8905 & 337 \\
\hline Leadership Quarterly & 10 & 2127 & 95 \\
\hline Journal of Applied Psychology & 9 & 1858 & 81 \\
\hline Journal of Organizational Behavior & 8 & 1019 & 64 \\
\hline $\begin{array}{l}\text { Journal of Occupational and } \\
\text { Organizational Psychology }\end{array}$ & 8 & 772 & 63 \\
\hline Journal of Management & 9 & 899 & 62 \\
\hline $\begin{array}{l}\text { European Journal of Work and } \\
\text { Organizational Psychology }\end{array}$ & 10 & 202 & 52 \\
\hline Personnel Review & 16 & 132 & 51 \\
\hline Organization Science & 9 & 3277 & 48 \\
\hline $\begin{array}{l}\text { Leadership and Organization } \\
\text { Development Journal }\end{array}$ & 11 & 123 & 45 \\
\hline
\end{tabular}

Analiza zajedničkih citata provedena je za tri različita vremenska razdoblja u kojima se javljaju zasebni klasteri. Klastere čine skupovi povezanih radova na temelju analize zajedničkih citata. Mjerenje sličnosti odnosno povezanosti radova temelji se na pretpostavci da su radovi koji se često zajedno citiraju povezani u većoj mjeri (Zupic i Čater, 2015.). Dakle, mjeri se frekvencija zajedničkog citiranja dvaju radova. Pritom je korišten softver VOS Viewer pomoću kojeg se na uvezenim podacima iz Web of Science baze podataka može jednostavno i brzo provesti ova analiza. 


\section{Razdoblje do 1999. godine}

U razdoblju do 1999. bio je ukupno 91 rad. Identificirana su tri klastera. U prvom klasteru literature uglavnom se radi o ranim početcima proučavanja kreativnosti kada se smatralo da ona ovisi o osobinama ličnosti (Dellas i Gaier, 1970.). Istraživanja poput onog Mackinnona (1962.) proučavala su uspješne ljude poznate po kreativnosti. Glavni cilj bio je odrediti osobine ličnosti koje se mogu povezati s kreativnosti. Također, razvijeni su i testovi kreativnosti sukladni tom pristupu (Mednick, 1962.). Međutim, naziru se novi smjerovi proučavanja kreativnosti odnosno uvodi se pojam organizacijske klime i naglašava njezin utjecaj. Po prvi puta se određuje pojam inovacije na organizacijskoj razini.

Drugi klaster odnosi se uglavnom na ranija istraživanja procesa kreativnog razmišljanja i osobnog razvoja, pojma originalnosti i novih tema u području kreativnosti. Iako se Barron (1955.) smatra da originalnost isto ovisi o osobinama ličnosti, važno je naglasiti da se definicije originalnosti i kreativnosti ipak razlikuju. Originalnost podrazumijeva određeni stupanj neuobičajenosti uz uvjet da mora biti i realistično. Za većinu autora, kod kreativnosti nije nužno neuobičajeno rješenje. Uvode se pojam inovativnosti organizacije i razvija mjerni instrument za taj konstrukt (Siegel i Kaemmerer, 1978.). Međutim, inovativnost se ne razlikuje u odnosu na pojam kreativnosti. Također, počinje se istraživati uloga lidera, tj. nadređenih u organizacijskim inovacijama.

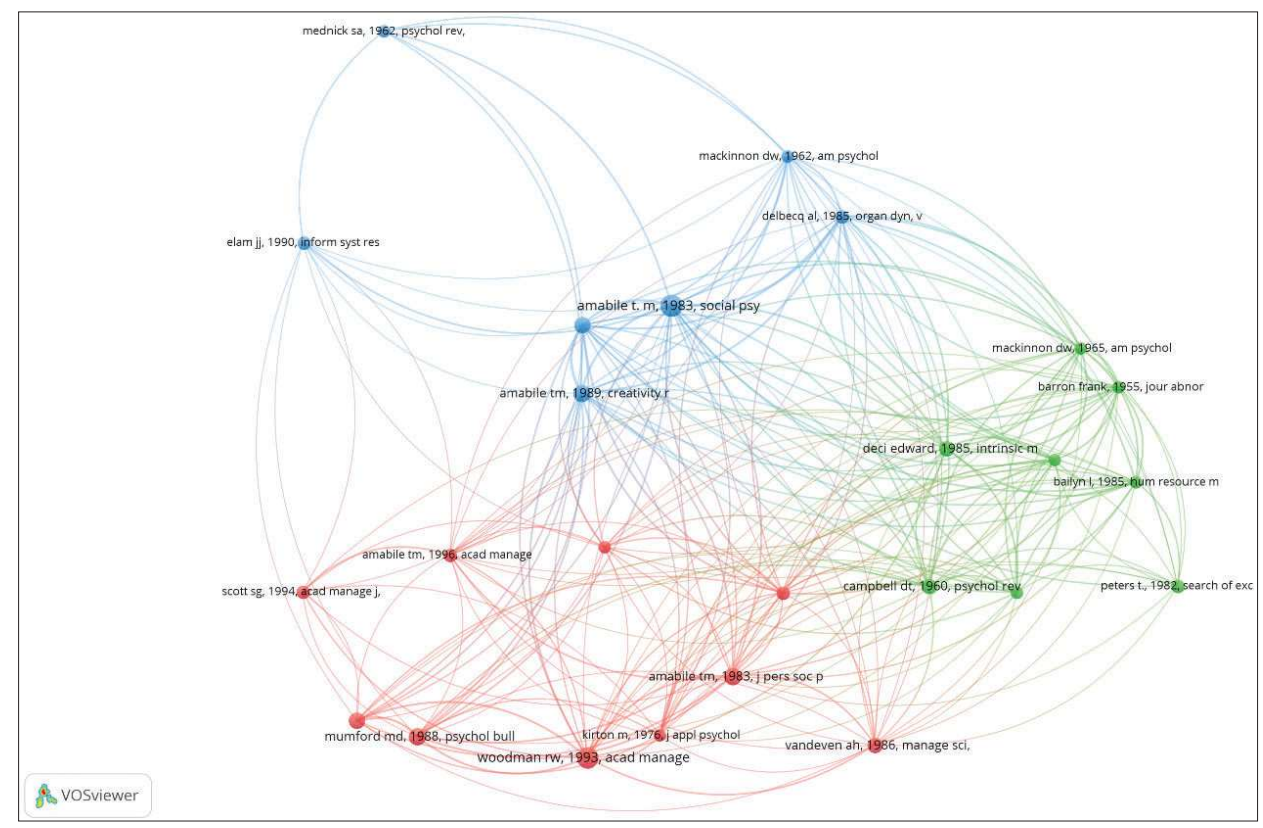

Slika 1. Vizualizacija klastera u razdoblju do 1999. godine

Treći klaster uglavnom se odnosi na radove koji redefiniraju pojam kreativnosti. Dugo je dominirao pristup koji se temeljio na crtama osobnosti. Novi pristup, pored osobnosti, uzima u obzir i utjecaj faktora okoline. Kreativnost je rezultat interakcije talenta, osobnosti, urođenih interesa, edukacije, kognitivnih vještina i motivacije (Amabile, 1983). Također, predlaže se nova definicija kreativnosti prema kojoj je nešto kreativno ako se prikladni promatrači neovi- 
sno slažu oko toga. Ukazuje se na problem neusklađenosti definicija kreativnosti u literaturi odnosno ističe se potreba za jedinstvenom definicijom. Razvijen je novi mjerni instrument za mjerenje svih dimenzija konteksta za koje se smatra da potiču kreativnost (Amabile, 1996.). Iako se još uvijek pojam inovacije u nekim radovima koristi umjesto kreativnosti, po prvi puta je definiran konstrukt inovativnog ponašanja pojedinca Scott i Bruce (1994.).

\section{Razdoblje od 2000. do 2009. godine}

U razdoblju od 2000. do 2009. godine bilo je ukupno 447 radova, od kojih je njih 250 najrelevantnijih uključeno u konačnu analizu zajedničkih citata. Identificirana su tri klastera. Međutim, radovi u prvom klasteru nisu toliko međusobno povezani (vidjeti sliku 2.). Potrebno je napomenuti kako bi zbog slabije međusobne povezanosti radove iz prvog klastera bilo moguće svrstati u preostala dva klastera. Prvi klaster najviše je vezan uz temu radne klime odnosno njenog utjecaja na kreativnost. Također, još uvijek je prisutno naizmjenično korištenje kreativnosti i inovativnosti. Ford (1996.) objašnjava svoju teoriju o važnosti radne klime na način da jedino ona može aktivirati pojedince koji po svojoj naravi nisu skloni kreativnom ponašanju odnosno skloni su rutinskom ponašanju.

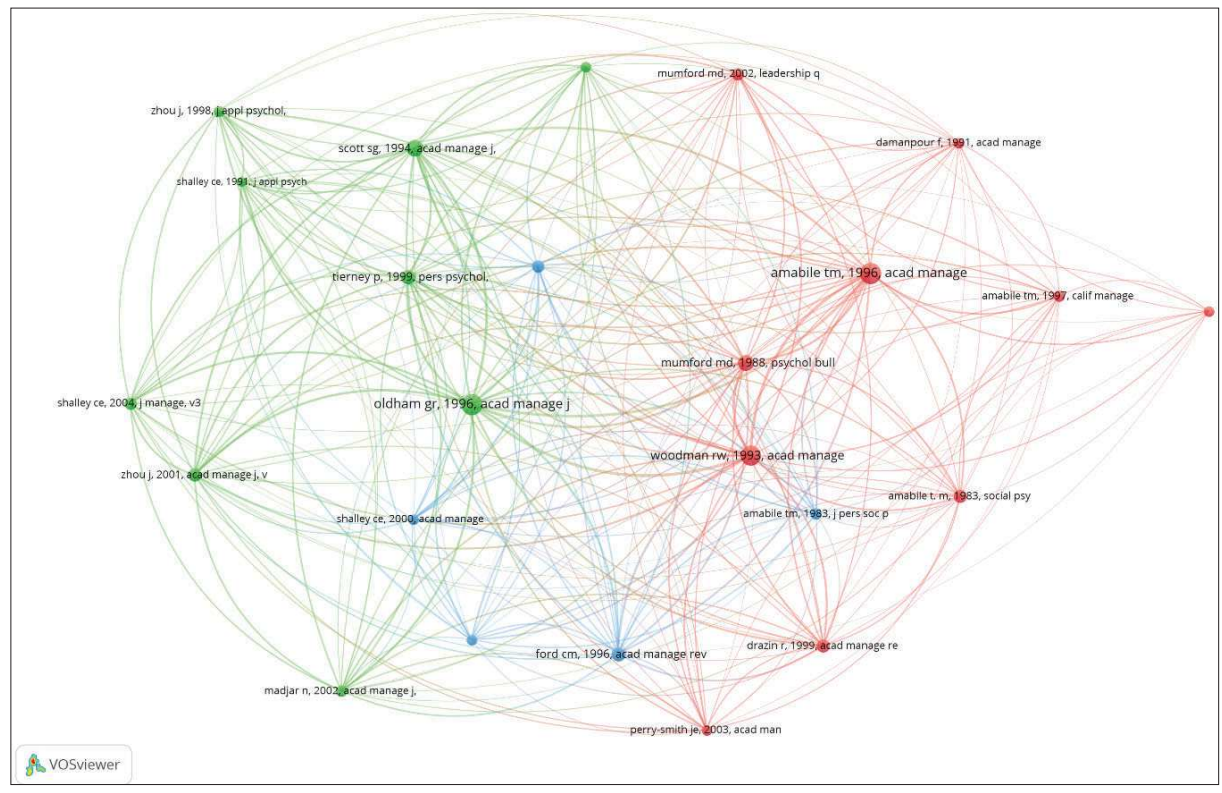

Slika 2. Vizualizacija klastera u razdoblju od 2000. do 2009. godine

Drugi klaster sastoji se od radova koji istražuju interakcije različitih čimbenika utjecaja na kreativnost i inovativnost. Tako su Oldham i Cummings (1996.) proveli empirijsko istraživanje utjecaja osobnih karakteristika zaposlenika i karakteristika organizacijskog konteksta (kompleksnost posla, razina podrške nadređenog, razina kontrole nadređenog) na kreativno ponašanje zaposlenika. Tierney i sur. (1999.) istražili su utjecaj interakcije osobnih karakteristika i kontekstualnih karakteristika na kreativno ponašanje. S obzirom na to da je prepoznata važnost okoline za kreativnost, vidljivo je da postoji sve više istraživanja 
na tu temu. Tako se i dizajn posla počeo istraživati u području kreativnosti. Primjerice, Shalley et al. (2004.) izdvojili su dizajn posla kao vrlo važan kontekstualan čimbenik. Prve varijable dizajna posla koje su istražene su kompleksnost posla, povratne informacije i autonomija. Također, sve više istraživanja bavi se inovativnim ponašanjem koje, za razliku od kreativnosti, uključuje implementaciju ideja.

Treći klaster temelji se na radu Amabile (1983.) odnosno prema novoj teoriji kreativnosti koja predstavlja odmak od pristupa kreativnosti koji se temeljio na crtama osobnosti. Razvijen je i novi mjerni instrument za mjerenje svih dimenzija konteksta za koje se smatra da utječu na kreativnost (Amabile, 1996.). Mumford i sur. (2002.) napravili su pregled literature utjecaja lidera (nadređenih) na kreativnost i inovativnost. Vrlo je zanimljivo što se kreativnost uglavnom istraživala na razini pojedinca, dok se inovativnost primarno istraživala na organizacijskoj razini. U tom smislu velik pomak su napravili Woodman i sur. (1993.) koji su naglasili potrebu za višerazinskim pristupom kreativnosti i inovativnosti. Predložili su teorijski okvir koji objašnjava interakcije između različitih razina (pojedinac, grupa, organizacijske karakteristike).

\section{Razdoblje od 2010. do 2019. godine}

U razdoblju od 2010. do 2019. godine bilo je ukupno 2703 radova, od kojih je 250 najrelevantnijih uključeno u konačnu analizu zajedničkih citata. Identificirana su tri klastera. Prvi klaster se primarno odnosi na istraživanje dizajna posla kao važnog prethodnika kreativnosti i inovativnosti. Razvijen je model karakteristika posla koji objašnjava mehanizam utjecaja karakteristika posla na ishode posla (Hackman i Oldham, 1976.). Također, razvijen je i set instrumenata za mjerenje karakteristika posla (Morgeson i Humphrey, 2006.). Axtell i sur. (2000.) pokazali su da su za kreativnost ključne karakteristike posla i osobne karakteristike, u odnosu na grupne i organizacijske karakteristike. Zanimljiva je i meta-analiza koja je ukazala na veliku važnost dizajna posla kao čimbenika utjecaja na ishode posla (Humphrey i sur., 2007.).

Drugi klaster se nastavlja na teoriju kreativnosti razvijenu od Amabile (1983.). Prema tzv. komponentnoj teoriji kreativnosti podrazumijeva se da u odgovarajućoj socijalnoj okolini svi ljudi s normalnim (prosječnim) sposobnostima barem u određenoj mjeri mogu biti kreativni (Amabile, 1997.). No javlja se i rad koji predlaže integrativnu definiciju kreativnosti i inovativnosti (Anderson i sur., 2014.). Ova definicija prepoznaje kreativnost i inovativnost kao proces, ishod i proizvod kojima se nastoji razviti nešto novo (Anderson i sur., 2014.). Pritom se kreativnost odnosi na prvi dio tog procesa, a inovativnost na drugi dio odnosno na implementaciju ideja. U ovom klasteru značajan je i novi konstrukt kreativnog samopouzdanja koji se pokazao važnim za kreativnost kao ishod (vidjeti Tierney i Farmer, 2002.; Gong i sur., 2009.). Također, važno je istaknuti i niz radova koji se bave metodama i preporukama za njihovo korištenje u području kreativnosti. To su primjerice, preporuke o korištenju metode modeliranja strukturnih jednadžbi (Anderson i Gerbing, 1988.) te preporuke za procjenjivanje indirektnih efekata (Preacher i Hayes, 2008.).

Treći klaster u ovom vremenskom razdoblju obilježava teorijska osnova u interakcijskom pristupu organizacijskoj kreativnosti. Prema tom pristupu, organizacijska kreativnost ovisi o kompleksnoj interakciji pojedinaca, grupa i organizacijskih karakteristika te konteksta (Woodman i sur., 1993.). Kao rezultat toga, vidljivo je da se radovi povezani s ovom teo- 
rijom bave širokim rasponom tema: od uloge lidera (nadređenih), dizajna posla, dimenzija ličnosti, kolega na poslu, nezadovoljstva poslom pa sve do utjecaja pozitivnog i negativnog afekta. Istraživao se i utjecaj interakcije osobnih karakteristika i kontekstualnih karakteristika na kreativno ponašanje. Tierney i sur. (1999.) pokazali su da intrinzična motivacija i kognitivan stil zaposlenika, intrinzična motivacija nadređenih te odnos između zaposlenika i nadređenog utječu na kreativnost zaposlenika. Podrška nadređenog ima pozitivan utjecaj na kreativnost zaposlenika, ali zanimljivo je to da postoje učinkoviti i neučinkoviti oblici podrške nadređenog (Amabile i sur., 2004.). Zatim, pokazalo se da kreativni kolege doprinose kreativnosti pojedinog zaposlenika i to posebno u situaciji kada ih njihovi nadređeni nadziru u manjoj mjeri (Zhou, 2003.).

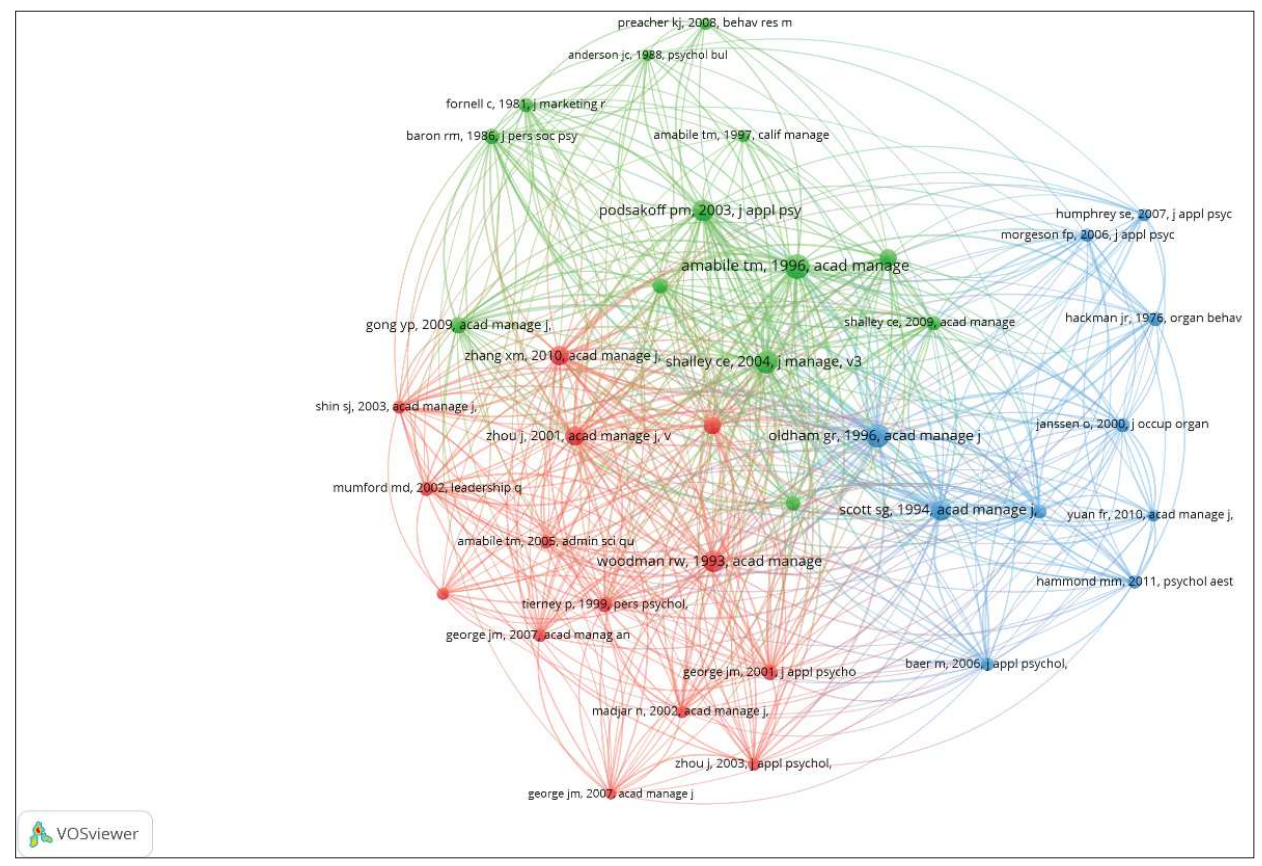

Slika 3. Vizualizacija klastera u razdoblju od 2010. do 2019. godine

\section{RASPRAVA I ZAKLJUČAK}

Prije rasprave o rezultatima analize, potrebno je spomenuti ograničenja ovoga istraživanja. Postoje tri značajna ograničenja. Prvo, provedene su samo dvije vrste bibliometrijske analize (citata i zajedničkih citata). Provođenjem dodatnih bibliometrijskih analiza poput analize zajedničkih riječi ili uparivanja, moguće je obogatiti pregled područja. Drugo, nije moguće u analizu uključiti sve starije radove iz razloga što nisu indeksirani u Web of Science bazi podataka. Nažalost, zbog te činjenice u pregledu literature sigurno je izostalo nekoliko zanimljivih radova. Treće, vidljiva je veća zastupljenost radova iz područja kreativnosti. Iako je provedena zajednička analiza kreativnosti i dizajna posla, očito je veći broj radova (u apsolutnom smislu) u području kreativnosti utjecao na njihovu veću zastupljenost u bibliometrijskoj analizi. 
Provedene su analize citata i zajedničkih citata s ciljem pružanja pregleda intelektualnog razvoja i strukture područja kreativnosti te njezine povezanosti s dizajnom posla. $\mathrm{Na}$ temelju klastera koji su se javljali u pojedinim vremenskim razdobljima vidljiva je struktura razvoja područja kreativnosti. Raniji radovi promatrali su kreativnost kao dio osobnog talenta i nastojali su odrediti crte ličnosti koje je moguće povezati s kreativnosti. Također, u razdoblju do 1999. godine nije postojala jedinstvena definicija kreativnosti, a slijedom toga niti jedinstven pristup mjerenju kreativnosti. Isto tako, iako je uveden pojam inovativnosti, vrlo često se koristio naizmjenično s kreativnosti. Pritom nije bilo bitne razlike između kreativnosti i inovativnosti.

Sljedeći važni koraci u razvoju su naglašavanje utjecaja radne klime i kontekstualnih karakteristika (Amabile, 1983.) te razvoj interakcijskog pristupa (Woodman i sur., 1993.). Također, ukazivanje na probleme oko definicije konstrukta dovelo je do primjetno većeg konsenzusa oko poimanja kreativnosti u razdoblju od 2000. do 2009. godine. Vrlo važan je bio rad Scotta i Brucea (1994.) u kojem je po prvi puta definirano inovativno ponašanje pojedinca, uz objašnjenje razlike u odnosu na kreativno ponašanje. Provedena su brojna istraživanja vezana uz utjecaj dizajna posla i vodstva (nadređenih) na kreativnost i inovativnost zaposlenika.

Spomenuto je nekoliko preporuka za unaprjeđenje područja kreativnosti. Prvo, predložena je integrativna definicija kreativnosti i inovativnosti s idejom objedinjenja ova dva usko povezana područja. Drugo, to otvara mogućnost istraživanja povezanosti kreativnosti i inovativnosti odnosno organizacijskih uvjeta koji omogućuju implementaciju ideja (Shalley i sur., 2004.). Treće, potrebno je istražiti više različitih karakteristika posla. Dosadašnja istraživanja uglavnom se bila usredotočena na mali broj specifičnih i izoliranih karakteristika posla (npr. kompleksnost posla, autonomija na poslu, podrška kolega). To je posebno važno s obzirom na to da je utvrđena velika važnost utjecaja dizajna posla na kreativnost.

Nadalje, provođenjem višerazinskih istraživanja omogućio bi se daljnji razvoj teorijskih okvira u području. Primjerice, o čemu ovisi hoće li kreativni pojedinci uspjeti implementirati svoju ideju, kako organizacijske politike utječu na implementaciju ideja, ili na koji način kreativni pojedinci mogu utjecati na organizacijsku klimu ili organizacijske politike? Posljednje, nedostaju istraživanja koja bi razjasnila koji doprinos kreativnost i inovativnost imaju na ishode na različitim organizacijskim razinama te isključuju li se možda međusobno inovativnost i učinkovitost.

\section{LITERATURA}

1. Amabile, T. M. (1983). The social psychology of creativity: A componential conceptualization. Journal of Personality and Social Psychology, 45(2), 357-376. http://dx.doi. org/10.1037/0022-3514.45.2.357.

2. Amabile, T. M. (1997). Motivating creativity in organizations: On doing what you love and doing what you do. California Management Review, 40(1), 38-58. https://doi. org/10.2307/41165921.

3. Amabile, T. M., Conti, R., Coon, H., Lazenby, J., \& Herron, M. (1996). Assessing the work environment for creativity. Academy of Management Journal, 39(5), 1154-1184. https://doi.org/10.5465/256995. 
4. Amabile, T. M., Schatzel, E. A., Moneta, G. B., \& Kramer, S. J. (2004). Leader behaviors and the work environment for creativity: Perceived leader support. Leadership Quarterly, 15(1), 5-32. https://doi.org/10.1016/j.leaqua.2003.12.003.

5. Anderson, J. C., \& Gerbing, D. W. (1988). Structural equation modelling in practice: A review and a recommended two-step approach. Psychological Bulletin, 103(3), 411423. http://dx.doi.org/10.1037/0033-2909.103.3.411.

6. Anderson, N., Potočnik, K., \& Zhou, J. (2014). Innovation and creativity in organizations: A state of the science review, prospective, commentary, and guiding framework. Journal of Management, 40(5), 1297-1333. https://doi.org/10.1177/0149206314527128.

7. Axtell, C. M., Holman, D. J., Unsworth, K. L., Wall, T. D., Waterson, P. E., \& Harrington, E. (2000). Shopfloor innovation: Facilitating the suggestion and implementation of ideas. Journal of Occupational and Organizational Psychology, 73(3), 265-285. https://doi.org/10.1348/096317900167029.

8. Barron, F. (1955). The disposition toward originality. Journal of Abnormal Psychology, 51(3), 478-485. https://doi.org/10.1037/h0048073.

9. Bos-Nehles, A. C. i Janssen, M. (2015). The Influence of HRM Practices on Innovative Work Behavior: a Systematic Literature Review. Paper presented at 9th International Conference of the Dutch HRM Network, Utrecht, Netherlands.

10. Castillo-Vergara, M., Alvarez-Marin, A., \& Placencio-Hidalgo, D. (2018). A bibliometric analysis of creativity field of business economics. Journal of Business Research, 85, 1-9. https://doi.org/10.1016/j.jbusres.2017.12.011.

11. Dellas, M., \& Gaier, E. L. (1970). Identification of creativity: The individual. Psychological Bulletin, 73(1), 55-73. http://dx.doi.org/10.1037/h0028446.

12. Drazin, R., Glynn, M. A., \& Kazanjian, R. K. (1999). Multilevel theorizing about creativity in organizations: A sensemaking perspective. Academy of Management Review, 24(2), 286-307. https://doi.org/10.2307/259083.

13. Ford, C. M. (1996). A theory of individual creative action in multiple social domains. Academy of Management Review, 21(4), 1112-1142. https://doi.org/10.2307/259166.

14. Gong, Y., Huang, J.-C., \& Farh, J.-L. (2009). Employee learning orientation, transformational leadership, and employee creativity: the mediating role of employee creative self-efficacy. Academy of Management Journal, 52(4), 765-778. https://doi. org/10.5465/amj.2009.43670890.

15. Grant, A. M. (2007). Relational job design and the motivation to make a prosocial difference, Academy of Management Review, 32(2), 393-417. https://doi.org/10.5465/ amr.2007.24351328

16. Grant, A. M., \& Parker, S. K. (2009). Redesigning Work Design Theories: The Rise of Relational and Proactive Perspectives. Academy of Management Annals, 3(1), 317 375. https://doi.org/10.5465/19416520903047327.

17. Hackman, J. R., \& Oldham, G. (1976). Motivationg through the design of work: Test of a theory. Organizational Behavior and Human Performance, 16(2), 250-279. https:// doi.org/10.1016/0030-5073(76)90016-7.

18. Hammond, M. M., Neff, N. L., Farr, J. L., Schwall, A. R. i Zhao, X. (2011) Predictors of individual-level innovation at work: A meta-analysis. Psychology of Aesthetics, Creativity, and the Arts, 5(1), str. 90-105. http://dx.doi.org/10.1037/a0018556. 
19. Humphrey, S. E., Nahrgang, J. D., \& Morgeson, F. P. (2007). Integrating motivational, social, and contextual work design features: A meta-analytic summary and theoretical extension of the work design literature. Journal of Applied Psychology, 92(5), 1332-1356. https://doi.org/10.1037/0021-9010.92.5.1332.

20. Mackinnon, D. W. (1962). The nature and nurture of creative talent. American Psychologist, 17(7), 484-495. https://doi.org/10.1037/h0046541.

21. Mayfield, C. O. (2013). Promoting organizational citizenship behavior through job design: Job characteristics versus job satisfaction. Journal of Business Disciplines, 11(1), str. 36-64.

22. Mednick, S. A. (1962). The associative basis of the creative process. Psychological Review, 69(3), 220-232. https://doi.org/10.1037/h0048850.

23. Morgeson, F. P., \& Humphrey, S. E. (2006). The work design questionnaire (WDQ): Developing and validating a comprehensive measure for assessing job design and the nature of work. Journal of Applied Psychology, 91(6). https://doi.org/1321-1339. 10.1037/0021-9010.91.6.1321.

24. Mumford, M. D., \& Gustafson, S. B. (1988). Creativity syndrome: Integration, application, and innovation. Psychological Bulletin, 103(1), 27-43. http://dx.doi. org/10.1037/0033-2909.103.1.27.

25. Mumford, M. D., Scott, G. M., Gaddis, B., \& Strange, J. M. (2002). Leading creative people: Orchestrating expertise and relationships. Leadership Quarterly, 13(6), 705750. http://dx.doi.org/10.1016/S1048-9843(02)00158-3.

26. Nerur, S. P., Rasheed, A. A., \& Natarajan, V. (2008). The intellectual structure of the strategic management field: An author co-citation analysis. Strategic Management Journal, 29, 319-336. https://doi.org/10.1002/smj.659.

27. Oldham, G. R., \& Cummings, A. (1996). Employee creativity: Perosnality and contextual factors at work. Academy of Management Journal, 39(3), 607-634. https://doi. org/10.2307/256657.

28. Parker, S. K., Wall, T. D., \& Cordery, J. L. (2001). Future work design research and practice: Towards an elaborated model of work design. Journal of Occupational and Organizational Psychology, 74(4), 413-440. https://doi.org/10.1348/096317901167460.

29. Preacher, K. J., \& Hayes, A. F. (2008). Asymptotic and resampling strategies for assessing and comparing indirect effects in multiple mediator models. Behavior Research Methods, 40(3), 879-891. https://doi.org/10.3758/BRM.40.3.879.

30. Scott, S. G., \& Bruce, R. A. (1994). Determinants of innovative behavior: A path model of individual innovation in the workplace. Academy of Management Journal, 37(3), 580-607. https://doi.org/10.2307/256701.

31. Shalley, C. E., Zhou, J., \& Oldham, G. R. (2004). The Effects of Personal and Contextual Characteristics on Creativity: Where Should We Go from Here? Journal of Management, 30(6), 933-958. https://doi.org/10.1016/j.jm.2004.06.007.

32. Siegel, S. M., \& Kaemmerer, W. F. (1978). Measuring the perceived support for innovation in organizations. Journal of Applied Psychology, 63(5), 553-562. http://dx.doi. org/10.1037/0021-9010.63.5.553. 
33. Sonnentag, S. (2003). Recovery, work engagement, and proactive behavior: a new look at the interface between nonwork and work. The Journal of applied psychology, 88(3), str. 518-528. http://dx.doi.org/10.1037/0021-9010.88.3.518.

34. Tierney, P., \& Farmer, S. M. (2002). Creative self-efficacy: Its potential antecedents and relationship to creative performance. Academy of Management Journal, 45(6), 1137-1148. http://dx.doi.org/10.2307/3069429.

35. Tierney, P., Farmer, S. M., \& Graen, G. B. (1999). An examination of leadership and employee creativity: The relevance of traits and relationships. Personnel Psychology, 52(3), 591-620. https://doi.org/10.1111/j.1744-6570.1999.tb00173.x.

36. Unsworth, K. L. i Parker, S. K. (2003). Proactivity and Innovation: Promoting a Proactive and Innovative Workforce for the New Workplace. U: Holman, D., Wall, T. D., Clegg, C. W., Sparrow, P. i Howard, A., ur., The New Workplace: A Guide to the Human Impact of Modern Working Practices. Chichester, UK: John Wiley i Sons, str. 175-196.

37. Van Eck, N. J., \& Waltman, L. (2010). Software survey: VOSviewer, a computer program for bibliometric mapping. Scientometrics, 84(2), 523-538. https://doi.org/10.1007/ s11192-009-0146-3.

38. Van Eck, N. J., Waltman, L., Dekker, R., \& Van den Berg, J. (2010). A comparison of two techniques for bibliometric mapping: Multidimensional scaling and VOS. Journal of the American Society for Information Science and Technology, 61(12), 24052416. https://doi.org/10.1002/asi.21421.

39. Vogel, R. \& Güttel, W. H. (2013). The dynamic capability view in strategic management: A bibliometric review. International Journal of Management Reviews, 15(4), 426-446. https://doi.org/10.1111/ijmr.12000.

40. Williams, R., Runco, M., \& Berlow, E. (2016). Mapping the themes, impact, and cohesion of creativity research over the last 25 years. Creativity Research Journal, 28(4), 385-394. https://doi.org/10.1080/10400419.2016.1230358.

41. Woodman, R. W., Sawyer, J. E., \& Griffin, R. W. (1993). Toward a theory of organizational creativity. Academy of Management Review, 18(2), 293-321. https://doi. org/10.2307/258761.

42. Xanthopoulou, D., Bakker, A. B., Demerouti, E. i Schaufeli, W. B. (2009). Work engagement and financial returns: A diary study on the role of job and personal resources. Journal of Organizational and Occupational Psychology, 82, str. 183-200. https://doi. org/10.1348/096317908X285633.

43. Zhou, J. (2003). When the presence of creative coworkers is related to creativity: Role of supervisor close monitoring, developmental feedback, and creative personality. Journal of Applied Psychology, 88(3), 413-422. https://doi.org/10.1037/00219010.88.3.413.

44. Zupic, I., \& Čater, T. (2015). Bibliometric methods in management and organization. Organizational Research Methods, 18(3), 429-472. https://doi. org/10.1177/1094428114562629. 